\title{
Studies on 4-allyloxy-3
}

chlorophenylacetic acid (Alclofenac)

\section{A double-blind comparison of Alclofenac and aspirin in rheumatoid arthritis, and effects of therapy on serum immunoglobulins and rheumatoid factor}

\author{
MANSEL AYLWARD, R. J. PARKER, AND J. MADDOCK \\ From the Research Division, Merthyr Tydfil General Hospital, and the Department of Pathology and \\ Biochemistry, Singleton Hospital, Swansea, Glamorgan
}

\begin{abstract}
Alclofenac (4-allyloxy-3 chlorophenylacetic acid) was prepared by Buu-Hoï, Lambelin, Gillet, Roba, and Staquet (1969) as one of a series of arylacetic acid derivatives, which exhibited potent analgesic antipyretic and anti-inflammatory effects in experimental animals (Lambelin, Roba, Gillet, and Buu-Hoï, 1970). The toxicity of the compound was found to be low and studies in several species, including dogs and monkeys, have revealed no gastric intolerance, even at doses several times the therapeutic range in man (Lambelin, Roba, Gillet, Gautier, and Buu-Hoï, 1970).
\end{abstract}

The pharmacodynamics of this compound have been well described in several animal species and in man (Roncucci, Simon, Lambelin, Gillet, and Kaisin, 1972). Alclofenac is well absorbed from the gastrointestinal tract, dose-related peak plasma concentrations occurring during the second hour after oral intake, and more than 90 per cent. being excreted in the urine within 48 hours.

Using a radioactive chromium technique, McLean Baird (personal communication, 1972) has shown that the mean daily blood-loss of $1.16 \mathrm{ml}$. during Alclofenac administration in a dosage of $3 \mathrm{~g}$. daily was not significantly different from control periods; by comparison, the same volunteers treated with $3 \cdot 6 \mathrm{~g}$. daily of soluble aspirin had a mean daily blood-loss of $4.14 \mathrm{ml}$. which was significantly greater than that during Alclofenac treatment and control periods. Preliminary clinical studies of Alclofenac in patients with rheumatoid arthritis have suggested that the drug has clinically useful analgesic and anti-inflammatory properties and a low incidence of side-effects (Ory, 1971; Aylward and Davies, 1972; Pavelka, Vojtíšek, Brémová, Kan̆ková and Handlová, 1973; Aylward, 1973).

In view of the potential advantage to patients with rheumatoid disease of an effective analgesic/anti- inflammatory drug which causes insignificant gastrointestinal bleeding, it was decided to undertake a study of Alclofenac and aspirin to compare the clinical efficacy of the two drugs and to monitor several haematological, serological, and biochemical parameters during the course of 17 weeks' continuous administration of each drug to matched groups of patients.

\section{Method}

\section{PATIENTS}

52 patients with classical or definite rheumatoid arthritis (Ropes, Bennett, Cobb, Jacox, and Jessar, 1959) entered the trial; 26 were to receive aspirin and 26 Alclofenac. Ten patients were subsequently withdrawn from the study: four from the aspirin group because of persistent indigestion, two from the Alclofenac group because of the appearance of a rash, two from the aspirin group because of symptoms of salicylism, and one from each group because of lack of analgesia. This left 23 patients in the Alclofenac group and nineteen in the aspirin group.

The characteristics of each group (shown in Table I) were found to be comparable.

Patients were excluded if they had any history of intolerance to either of the trial agents, or had received steroids, gold salts, or chloroquine within the previous year. Pregnancy was excluded in those of child-bearing age by testing the urine at fortnightly intervals with the 'prepurex test.'

\section{DOSAGE}

The drugs were administered as identical capsules and the patients were allocated to one of the treatment schedules according to a predetermined random code. The daily dosage of aspirin was $4.8 \mathrm{~g}$. and of Alclofenac $3 \mathrm{~g}$., each being administered in three equal doses per day. No other anti-inflammatory or analgesic agents were allowed and physiotherapy and wax baths were discontinued for the duration of the trial. 
Table I Comparability of the two treatment groups

(None of the differences are significant at 10 per cent. level)

\begin{tabular}{|c|c|c|}
\hline Treatment & $\begin{array}{l}\text { Aspirin } \\
(\mathbf{4} \cdot 8 \mathrm{~g} .)\end{array}$ & $\begin{array}{l}\text { Alclofenac } \\
(3.0 \mathrm{~g} .)\end{array}$ \\
\hline Total no. of patients & 19 & 23 \\
\hline Mean age (yrs) \pm SD & $50 \pm 8 \cdot 0$ & $52 \pm 8 \cdot 0$ \\
\hline $\begin{array}{ll}\text { Sex } & \text { Male } \\
\text { Female }\end{array}$ & $\begin{array}{r}5 \\
14\end{array}$ & $\begin{array}{r}8 \\
15\end{array}$ \\
\hline $\begin{array}{l}\text { Functional Grade } \\
\text { I } \\
\text { II } \\
\text { III } \\
\text { IV }\end{array}$ & $\begin{array}{l}8 \\
7 \\
3 \\
1\end{array}$ & $\begin{array}{l}6 \\
9 \\
5 \\
3\end{array}$ \\
\hline $\begin{array}{l}\text { Pain score at initial assessment } \\
\quad(\text { Mean } \pm \text { S.E. })\end{array}$ & $2 \cdot 72 \pm 0 \cdot 10$ & $2.73 \pm 0.09$ \\
\hline $\begin{array}{l}\text { Duration of disease (yrs) } \\
\quad 1-5 \\
6-10 \\
11-15 \\
\text { More than } 15\end{array}$ & $\begin{array}{r}10 \\
4 \\
3 \\
1\end{array}$ & $\begin{array}{r}12 \\
5 \\
3 \\
2\end{array}$ \\
\hline $\begin{array}{l}\text { Median no. of inflamed joints } \\
\text { Patients with erosions } \\
\text { Patients with nodules }\end{array}$ & $\begin{array}{r}15 \\
7 \\
18\end{array}$ & $\begin{array}{r}14 \\
8 \\
23\end{array}$ \\
\hline Articular index (median score) & 12 & 14 \\
\hline $\begin{array}{l}\text { Duration of morning stiffness (min.) } \\
\text { (Mean } \pm \text { S.D.) }\end{array}$ & $194 \pm 20$ & $196 \pm 19$ \\
\hline $\begin{array}{l}\text { Grip strength at initial assessment } \\
\text { (mm. Hg) } \\
\text { Total of both hands (Mean } \pm \text { S.D.) }\end{array}$ & $200 \pm 51 \cdot 2$ & $189 \pm 38 \cdot 6$ \\
\hline $\begin{array}{l}\text { Digital joint size (mm.) } \\
\quad(\text { Mean } \pm \text { S.D.) }\end{array}$ & $497 \pm 25$ & $492 \pm 30$ \\
\hline
\end{tabular}

\section{ASSESSMENT}

After the initial assessment, each patient was given placebo capsules identical in appearance with the trial agents. Although it was decided to administer the placebo capsules for 7 days, because of the distressing effects of lack of analgesia in 75 per cent. of the patients after 3 days without any analgesic/anti-inflammatory drug, this interval was reduced to $72 \mathrm{hrs}$ before the second assessment, when the active drugs were started. After this, further assessments were made after $1,5,9$, and 13 weeks, and, at the end of the trial, at 17 weeks. The clinical, subjective, and objective measures recorded at each visit are shown in Table $I$.

\section{Pain}

This was assessed according to the following grading: 0 -none, 1 -mild, 2-moderate, and 3-severe, by the patients' subjective assessment.

\section{Functional grade}

This was assessed on a four-point graded scale based on ability to carry out daily activities (Aylward and Davies, 1972).

\section{Articular index}

The method of scoring the pain on palpating the joints on a four-point scale (0-1-2-3) as described by Ritchie, Boyle, McInnes, Jasani, Dalakos, Grieveson, and Buchanan
(1968) was used, except that the ankle, talo-calcaneal, and mid-tarsal joints were taken as a single unit, since in several cases of severe inflammation, it was found impossible to differentiate between them.

\section{Laboratory investigations}

A full blood count and erythrocyte sedimentation rate, blood urea, serum uric acid, serum bilirubin, standard liver function tests, and serum enzymes (SGOT, SGPT, and $\mathrm{LDH}$ ) were recorded at each visit. Serum immunoglobulin levels were determined by radial immunodiffusion in agar-antibody plates (Behring immunodiffusion plates Hoechst pharmaceuticals, Hounslow, Middlesex). Tests for rheumatoid factor activity were performed after initial heat inactivation at $56^{\circ} \mathrm{C}$. for $30 \mathrm{~min}$.; activity was measured at $22^{\circ} \mathrm{C}$. using latex particles coated with aggregated human gamma globulin and sheep red cells sensitized with rabbit gamma globulin.

Latex-agglutination titres greater than 1:40 were considered to be abnormal.

\section{Results}

The clinical results of the trial are summarized in Table II (overleaf).

At each assessment made before the 13 th week, both treatments produced an equal reduction in pain scores, in articular index, and in the total number of inflamed joints. Thereafter, to the end of the study, improvement based on the results of these three parameters was significantly greater in the Alclofenac group (Table II). Improvement in duration of morning stiffness and in grip strength occurred in both groups, but a statistically significant improvement in favour of Alclofenac was attained from the 9th week to the end of the study.

Throughout the study, there were no significant changes in digital joint size in either group taken as a whole.

In the Alclofenac-treated group, eight patients improved by at least one functional grade during the 17-week treatment period and in no instance was there a deterioration to a more severe grade. This represents a statistically significant change (Wilcoxon signed-rank test: $n=8 ; P=0.001$ in a one-sided test).

In the aspirin-treated group, six patients improved by at least one functional grade, and one deteriorated by one grade. This does not represent a statistically significant change (Wilcoxon signed-rank test : $n=6$; $r=3 \cdot 5 ; P>0 \cdot 1$ in a one-sided test).

\section{LABORATORY DATA \\ Haematology}

Throughout the period of the trial there were no consistent changes in the measurements of haemoglobin concentrations, white cell and platelet counts.

The Alclofenac-treated patients showed a median fall of 55 per cent. in ESR measurements during 17 weeks. Analysis of the changes in ESR indicated a statistically significant reduction at the end of the 
Table II Improvement in clinical measures as compared with initial assessment

\begin{tabular}{|c|c|c|c|}
\hline Treatment & Aspirin & Alclofenac & $\begin{array}{l}\text { Significance of } \\
\text { difference between } \\
\text { drug groups }\end{array}$ \\
\hline $\begin{array}{l}\text { Pain score at week } 17 \\
\text { (Mean } \pm \text { S.E. of percentage improvement) }\end{array}$ & $35 \pm 10$ & $57 \pm 12$ & $P<0.05$ \\
\hline $\begin{array}{l}\text { Articular index score } \\
\text { (Mean } \pm \text { S.E. of reduction) } \\
\text { Week } 9 \\
\text { Week } 13 \\
\text { Week } 17\end{array}$ & $\begin{array}{l}4.3 \pm 0.33 \\
4.3 \pm 0.41 \\
4.6 \pm 0.44\end{array}$ & $\begin{array}{l}4.8 \pm 0.34 \\
5.7 \pm 0.36 \\
6.0 \pm 0.44\end{array}$ & $\begin{array}{l}P=0.05 \\
P<0.05\end{array}$ \\
\hline $\begin{array}{l}\text { Mean grip strength (both hands) } \\
\text { (Mean } \pm \text { S.E. of percentage improvement) } \\
\text { Week } 9 \\
\text { Week } 13 \\
\text { Week } 17\end{array}$ & $\begin{array}{l}27 \pm 12 \\
32 \pm 13 \\
36 \pm 16\end{array}$ & $\begin{array}{l}36 \pm 12 \\
38 \pm 12 \\
42 \pm 15\end{array}$ & $\begin{array}{l}P<0.05 \\
P<0.05 \\
P<0.05\end{array}$ \\
\hline $\begin{array}{l}\text { Duration of morning stiffness } \\
\text { (Mean } \pm \text { S.E. of reduction in min.) } \\
\text { Week } 9 \\
\text { Week } 13 \\
\text { Week } 17\end{array}$ & $\begin{array}{l}124 \pm 35 \\
125 \pm 26 \\
106 \pm 42\end{array}$ & $\begin{array}{l}146 \pm 36 \\
168 \pm 34 \\
193 \pm 40\end{array}$ & $\begin{array}{l}P<0.05 \\
P<0.05 \\
P<0.01\end{array}$ \\
\hline $\begin{array}{l}\text { Total inflamed joints } \\
\text { (Mean } \pm \text { S.E. reduction) } \\
\text { Week } 9 \\
\text { Week } 13 \\
\text { Week } 17\end{array}$ & $\begin{array}{l}3.8 \pm 0.5 \\
2.9 \pm 0.3 \\
2.4 \pm 0.2\end{array}$ & $\begin{array}{l}4.8 \pm 0.4 \\
4.6 \pm 0.5 \\
5.0 \pm 0.4\end{array}$ & $\begin{array}{l}\mathrm{P}<0.05 \\
\mathrm{P}<0.01\end{array}$ \\
\hline
\end{tabular}

treatment with Alclofenac (Wilcoxon signed-rank test: $\mathbf{P}=0.02$ in a one-sided test).

In the aspirin-treated patients there was a median fall of 31 per cent. in the ESR measurements, whilst in five patients there was a mean increase in ESR of 39 per cent. (SD $=36$ per cent. This did not represent a statistically significant change $(r=1 \cdot 42 ; \mathrm{P}>0 \cdot 1)$.

Comparison of the measurements of ESR in the two treatment groups at initial assessment and after 17 weeks revealed that the statistically significant difference between the treatment groups after 17 weeks' therapy $(P<0.05)$ was not present at initial assessment $(\mathbf{P}>\mathbf{0} \cdot \mathbf{1})$.

\section{Biochemistry}

The serum enzyme investigations showed no regular pattern of change during the trial. The total LDH and SGOT activities were raised in three patients from each group before participating in the trial. In all but one of these (a patient in the aspirin-group) the LDH and SGOT levels returned to normal. In the other patients LDH activity increased after 6 to 8 weeks' treatment in five patients (four receiving aspirin and one receiving Alclofenac). No significant changes were noted in standard liver function tests, blood urea, or serum uric acid.

\section{Rheumatoid factor titres and serum immuno- globulins}

92 per cent. of patients in the trial showed hypergammaglobulinaemia with raised levels of $\operatorname{IgG}, \operatorname{IgA}$, and IgM (Table III). There was no significant difference from baseline values in individual immunoglobulin levels in patients of either group at 9 weeks. At 17 weeks individual serum IgG levels in patients receiving Alclofenac were lower, but the change did not reach statistical significance (Table III: $0 \cdot 1>$ $P>0.05)$.

However, there was a reduction in serum IgM levels at 17 weeks which just reached statistical significance $(P=0.05)$. In contrast the aspirin-treated group showed no reduction in levels of IgM or IgG (Table III). Comparison of the Alclofenac group with the aspirin group indicated a statistically significant difference in IgM levels at 17 weeks $(P<0.05)$. Serum IgA levels did not change in any noticeable manner during treatment with either drug.

Analysis of the changes, by a ranking procedure, in latex-agglutination titres during 17 weeks in each treatment group indicated that there was a statistically significant fall in titres in the Alclofenac group, (Wilcoxon signed-rank test: $n=10 ; r=0 ; P=0.02$ ) which did not occur in the patients treated with aspirin $(n=7 ; r=11.0 ; \mathrm{P}>0.2)$.

\section{CORRELATION BETWEEN DISEASE STATE, ESR, AND SEROLOGY}

There was a highly significant correlation between the recorded decrease in ESR values and the decline in articular indices after 17 weeks of Alclofenac therapy $\left(D^{2}+T=744.00\right.$; Spearman's rank correlation test; $P<0.01)$. A correlation between ESR values and 
Table III Effect of each treatment on serum immunoglobulins in both groups of patients and values in normal adult controls

\begin{tabular}{|c|c|c|c|c|c|c|c|}
\hline \multirow{2}{*}{$\begin{array}{l}\text { Serum immumo- } \\
\text { globulin } \\
\text { (mg. per cent.) }\end{array}$} & \multicolumn{3}{|c|}{ Aspirin group (19) } & \multicolumn{3}{|c|}{ Alclofenac group (23) } & \multirow{2}{*}{$\begin{array}{l}\text { Healthy adult } \\
\text { (controls (40) }\end{array}$} \\
\hline & 0 weeks & 9 weeks & 17 weeks & 0 weeks & 9 weeks & 17 weeks & \\
\hline $\begin{array}{l}\text { IgG } \\
\quad(\text { Mean } \pm \text { SE) } \\
\quad \stackrel{(\text { Mean } \pm S E)}{\text { IgA }}\end{array}$ & $\begin{array}{l}2,921 \pm 170 \\
508 \pm 28\end{array}$ & $\begin{array}{l}2,936 \pm 131 \\
462 \pm 48\end{array}$ & $\begin{array}{l}3,059 \pm 195 \\
520 \pm 66\end{array}$ & $\begin{array}{l}3,230 \pm 120 \\
489 \pm 74\end{array}$ & $\begin{array}{l}2,849 \pm 142 \\
389 \pm 103\end{array}$ & $\begin{array}{l}1,785 \pm 192^{*} \\
542 \pm 68\end{array}$ & $\begin{array}{l}980 \pm 162 \\
140 \pm 76\end{array}$ \\
\hline $\begin{array}{l}\text { IgM } \\
(\text { Mean } \pm \text { SE })\end{array}$ & $167 \pm 19$ & $192 \pm 23$ & $158 \pm 17$ & $162 \pm 13$ & $186 \pm 29$ & $86 \pm 15 \dagger$ & $70 \pm 15$ \\
\hline
\end{tabular}

* Paired-data analysis of IgG change within the Alclofenac-group indicated a reduction at 17 weeks $(t=1.69 ; 0.1>P>0.05)$.

+ Paired-data analysis of IgM changes within the Alclofenac group showed a significant reduction at 17 weeks $(t=2 \cdot 0196 ; P=0.05)$ and difference in IgM levels between treatment groups was significant at 17 weeks $(t=2 \cdot 127 ; \mathrm{P}<0.05)$.

change in articular index was not proven in the aspirin-treated group $\left(D^{2}+T=601 ; P>0 \cdot 1\right)$. In those receiving Alclofenac, the correlation between the decline in IgM levels and the fall in latex titres after 17 weeks of therapy just reached statistical significance $\left(D^{2}+T=1,187 ; P=0.05\right)$.

There was no significant change in sheep cell agglutination titres in either group of patients.

\section{SIDE-EFFECTS (Table IV)}

There were fewer spontaneous complaints in the Alclofenac group than in the aspirin group. In particular, the frequency of gastrointestinal upset was greater in the aspirin group.

\section{Discussion}

The results of the present study have shown that Alclofenac is an effective analgesic for the treatment of active rheumatoid arthritis. A significant antiinflammatory effect of this drug, as measured by a reduction in the erythrocyte sedimentation rate, was also demonstrated. Boardman and Hart (1967) have suggested that a reduction in the circumference of the proximal interphalangeal joints of the hands is a good index of anti-inflammatory effect, but these authors emphasized that this reduction can only be obtained in a relatively small number of patients with active synovitis and reversible joint swelling. A randomly selected group of patients with rheumatoid disease will usually consist of patients who do not fulfil the strict criteria essential for the demonstration of the small but significant change in joint size. In the present study, it was not surprising, therefore, that no significant change in joint size was found in either group of randomly selected patients. The Alclofenac-treated group showed a significantly greater reduction in articular index and in the number of inflamed joints than did the aspirin group. Although both groups experienced an improvement in grip strength and a reduction in the duration of morning stiffness, the improvement on Alclofenac was significantly greater after the ninth week of treatment.
Table IV Side-effects encountered during 17 weeks treatment

\begin{tabular}{l} 
Dosage regime \\
\hline Total number of patients \\
with side-effects including \\
those withdrawn \\
\hline Total side-effects reported: \\
Epigastric pain \\
Abdominal 'fullness' \\
Nausea \\
Constipation \\
Vertigo and tinnitus \\
Macular rash \\
Sleep disturbance \\
Nocturia
\end{tabular}

Total number of side-effects

\begin{tabular}{|c|c|}
\hline $\begin{array}{l}\text { Aspirin } \\
(4.8 \mathrm{~g} . / \text { day })\end{array}$ & $\begin{array}{l}\text { Alclofenac } \\
\text { (3 g./day) }\end{array}$ \\
\hline $\begin{array}{l}15 \\
(65 \text { perc }\end{array}$ & $\begin{array}{l}7(30 \text { per } \\
\text { cent }) .^{*}\end{array}$ \\
\hline
\end{tabular}

\begin{tabular}{l}
\hline \\
5 \\
6 \\
4 \\
3 \\
3 \\
0 \\
1 \\
1 \\
\hline
\end{tabular}

23

\begin{tabular}{l}
0 \\
3 \\
2 \\
1 \\
0 \\
2 \\
2 \\
1 \\
\hline
\end{tabular}

11
* One patient was withdrawn from each group because of lack of analgesia.

Whereas Boardman and Hart (1967) demonstrated a measurable anti-inflammatory response with aspirin at total daily doses in excess of $5 \mathrm{~g}$., this dosage is too often accompanied by an unacceptably high incidence of adverse effects to permit long-term therapy, and in this trial a daily dose of $4.8 \mathrm{~g}$./day aspirin was chosen for comparison with a dose of $3 \mathrm{~g}$./day Alclofenac.

At a dose of $3 \mathrm{~g}$. daily, Alclofenac was well tolerated and gave rise to fewer side-effects than $4.8 \mathrm{~g}$./day aspirin. In particular, gastrointestinal side-effects were far less common in the Alclofenac group.

There have been no previous reports of the effect of Alclofenac on serum immunoglobulins and rheumatoid factor. It remains to be seen in further studies if Alclofenac is capable of producing a drug-induced diminution in the levels of serum IgG and IgM, which are reported in the present paper.

If Alclofenac does exert such an action, the mechanism by which it achieves this effect is unknown. Bluestone and Goldberg (1973) have demonstrated that penicillamine therapy results in a significant 
fall in serum IgG and IgM levels, which was noticeable after 3 months' treatment but more marked at 6 months. The authors suggested that the results of their study might be explained by a central immunosuppressive action of penicillamine.

The premise upon which the present study is offered is that the change in the laboratory parameters observed in the Alclofenac-treated patients did not occur in a comparable group of patients receiving aspirin. With such a small population and the relatively short period of 17 weeks' monitoring, it is not justifiable to draw any firm conclusions about the effect of Alclofenac on serum immunoglobulins and rheumatoid factor titres. However, the results furnish sufficient evidence to merit further studies to find out whether this chemical selectively suppresses the characteristic immunological disturbances found in rheumatoid diseases.

\section{Summary}

A double-blind between-patient trial over 17 weeks to compare the effects of aspirin $4.8 \mathrm{~g}$. daily with Alclofenac $3 \mathrm{~g}$. daily, was completed in 42 outpatients with rheumatoid arthritis.

Alclofenac produced a significantly greater reduction in the duration of morning stiffness, in the total number of inflamed joints, and in the total articular index than aspirin. At each assessment both groups showed a progressive improvement in overall pain scores and in grip strength; after 9 weeks this improvement was significantly greater for the Alclofenactreated patients. Only in the Alclofenac group was there a significant improvement in functional grade and reduction in erythrocyte sedimentation rate at the end of the trial.

No significant changes were found in either group in total digital joint size.

The study also reports a significant lowering of serum IgM levels and a marked decline in serum IgG levels during the administration of Alclofenac. No such effect was detected in the group of patients receiving aspirin, and neither group exhibited any discernible changes in IgA levels.

The observed decline in serum IgM levels showed significant correlation with a significant fall in latexagglutination titres, but not in sheep cell titre.

The implications of the observed reduction in serum IgG and IgM levels during Alclofenac therapy are discussed.

We wish to thank the medical and nursing staff who helped with this study, Dr. R. C. Ryder and Dr. F. Holly for reporting the results of laboratory data, and Dr. D. Meredith Williams and Dr. W. L. R. Kenyon for permitting some of the patients under their care to enter the trial. Berk Pharmaceuticals Limited are thanked for the provision of the trial materials; Mrs. Sandra Thomas for her secretarial assistance; and the patients for attending for frequent examinations.

\section{References}

Aylward, M. (1973) Brit. J. clin. Pract., 27, 255 (Alclofenac in rheumatoid arthritis: An evaluation of its anti-inflammatory and analgesic effects)

AND DAVIEs, D. B. S. (1972) Ibid., 26, 517 (A double-blind crossover trial comparing a new antirheumatic agent, Alclofenac, with phenylbutazone in chronic rheumatic disorders)

Bluestone, R., ANd Goldberg, L. S. (1973) Ann. rheum. Dis., 32, 50 (Effect of D-penicillamine on serum immunoglobulins and rheumatoid factor)

BoARdman, P. L., AND HaRT, F. Dudley (1967) Brit. med. J., 4, 264 (Clinical measurement of the antiinflammatory effects of salicylates in rheumatoid arthritis)

Bư-Hoï, N. P., Lambelin, G., Gillet, C., Roba, J., and StaQuet, M., (1969) Naturwissenschaften, 56, 330 (4-allyloxy-3 chlorophenylacetic acid, a new type of analgesic, antipyretic and antiphlogistic drug)

Lambelin, G., Roba, J., Gillet, C., and Bư-Hoï, N. P. (1970) Arzneim-forsch., 20, 610 (Pharmacology of a new analgesic, antipyretic and anti-inflammatory agent: 4-allyloxy-3 chlorophenylacetic acid)

,,-- GAUTIER, M., AND BUUU-HoÏ, N. P. (1970) 20, 618 (Toxicity studies of 4-allyloxy-3 chlorophenylacetic acid) Ibid., 20,618

MCLeAN BAIRD, I. (1972) Personal communication (An assessment of gastrointestinal bleeding using Alclofenac compared with aspirin)

Pavelka, K., Vojtíśek, O., Brémová, A., KañKová, D., and Handlová, D., (1973) Curr. med. Res. Opin., 1, 342 (Double-blind comparison of Alclofenac and phenylbutazone in the short-term treatment of rheumatoid arthritis)

ORY, M. (1971) Brux-méd., 51, 615 (Étude clinique de l'alclofénac oral et parentéral dans des affections rhumatismales aiguës)

Ritchie, D. M., Boyle, J. A., Mcinnes, J. M., Jasani, M. K., Dalakos, T. G., Grieveson, P., and BuChaNAN, W. W. (1968) Quart.J. Med., 37, 393 (Clinical studies with an articular index for the assessment of joint tenderness in patients with rheumatoid arthritis)

Roncucci, R., Simon, M. J., Gillet, C., Lambelin, G., AND Kaisin, M. (1972) In 'Proceedings of the International Symposium on Gas Chromatography/Mass Spectrometry-Elba, Italy', ed. A. Frigerio, p. 431. Tamburini, Milano (Characterization of Alclofenac metabolites in various animal species)

Ropes, M. W., Bennett, G. A., Cobb, S., JACOX, R., ANd Jessar, R. A. (1959) Ann. rheum. Dis., 18, 49 (Diagnostic criteria for rheumatoid arthritis) 